\title{
HUBUNGAN KESEGARAN JASMANI TERHADAP HASIL BELAJAR SISWA PUTRA KELAS VIII SMP NEGERI 6 TEBING TINGGI
}

\author{
Sutrisno
}

Surel: sstrisno24@gmail.com

\begin{abstract}
ABSTRAK
Tujuan dari penelitian ini adalah untuk mengetahui tingkat kesegaran jasmani siswa dan hasil belajar siswa, serta untuk mengetahui hubungan antara tingkat kesegaran jasmani terhadap hasil belajar siswa kelas VIII SMP Negeri 6 Tebing Tinggi. Populasi dalam penelitian ini adalah siswa kelas VIII SMP Negeri 6 Tebing Tinggi kelas pilihan yang berjumlah 92 siswa. Sampel dalam penelitian ini berjumlah 30 siswa. Teknik sampling yang digunakan adalah random sampling. Metode pengambilan data menggunakan metode survey dengan metode Tes Kesegaran Jasmani Indonesia (TKJI) dan dokumentasi. Data dari hasil tes diolah dengan menggunakan komputerisasi dengan sistem SPSS versi 16. Hasil penelitian menunjukkan : 1) tingkat kesegaran jasmani siswa putra kelas VIII SMP Negeri 6 Tebing Tinggi dalam kategori sedang. 2) hasil belajar siswa putra kelas VIII SMP Negeri 6 Tebing Tinggi dalam kategori baik. 3) terdapat hubungan positif yang signifikan antara tingkat kesegaran jasmani dengan hasil belajar siswa putra kelas VIII SMP Negeri 6 Tebing Tinggi tahun 2017. bagi siswa diharapkan selalu menjaga dan memperbaiki kesegaran jasmaninya sebagai bekal utama melakukan proses belajar.
\end{abstract}

Kata Kunci: Kesegaran Jasmani dan Hasil Belajar

\section{PENDAHULUAN}

Pendidikan merupakan wahana pokok bagi pengembangan kualitas sumber daya manusia. Dengan adanya pendidikan, manusia semakin sadar akan pentingnya proses berpikir untuk menentukan kualitas masa depannya. Melalui pendidikan seseorang dapat menentukan masa depannya di mulai dari bangku sekolah. Banyak pula yang meyakini bahwa pendidikan dan ilmu pengetahuan merupakan hal yang mutlak dibutuhkan untuk bisa bertahan di era persaingan global yang sedang terjadi di setiap bangsa.Pendidikan memang tidak hanya diperoleh dari bangku sekolah melainkan dari berbagai sumber diantaranya lingkungan pergaulan, lingkungan keluarga maupun dari media pemberitaan baik itu cetak maupun elektronik. Namun pendidikan formal tetaplah harus didapatkan di lingkungan sekolah yang merupakan satuan pendidikan yang sistem pendidikan dan pengajarannya telah dirancang secara teratur untuk menularkan pengetahuan kepada siswa-siswanya. Oleh karena itu, upaya peningkatan mutu pendidikan perlu mendapat perhatian yang sungguh-sungguh terutama di sekolah yang merupakan pondasi bagi seluruh jenjang pendidikan, karena dasar-dasar ilmu, kecakapan dan perilaku diberikan, sehingga perlu mendapatkan perhatian dan pembinaan yang seksama dengan senantiasa meningkatkan kualitasnya melalui suatu pola pembinaan wawasan keunggulan. Perkembangan sekolah tidak dapat dilepaskan dari perkembangan pendidikan yang ada. Sekolah sebagai satuan pendidikan 
formal memegang peranan yang penting untuk dapat mendidik dan mengajarkan kepada siswanya berbagai ilmu pengetahuan dan teknologi yang berkembang dalam kehidupan masyarakat. Sekolah yang lebih menonjolkan standar mutu pengajarannya biasanya menjadi pilihan dari para calon orang tua murid sebagai tempat untuk menyekolahkan anaknya. Hampir dipastikan bahwa jumlah kuota penerimaan siswa baru setiap tahunnya selalu jauh dibawah angka pendaftar, akibatnya harus selalu dilakukan seleksi yang ketat untuk menentukan calon murid terpilih yang nantinya dapat bersekolah di sekolah tersebut. Seleksi yang dilakukan biasanya dominan berkaitan dengan tes potensi akademik sehingga dapat dipastikan bahwa calon siswa yang dapat diterima di sekolah tersebut haruslah cerdas dalam berbagai mata pelajaran yang diujikan. Budaya pendidikan yang menonjolkan aktivitas kognitif begitu dominan terdapat pada sistem pendidikan di Indonesia. Banyak pelajar yang dituntut cerdas secara akademik dan mengesampingkan potensi kecerdasan lainnya. Jika dicermati lebih luas dan mendalam, terdapat kemampuan cipta, rasa dan karsa yang berseberangan dengan kecerdasan kognitif secara umum. Diantaranya melalui seni dan olahraga, seorang siswa juga dapat mengukir prestasi yang dapat membangun kebanggaan bagi dirinya dan orang-orang disekitarnya. Olahraga pada khususnya merupakan bidang yang hendaknya selalu dikembangkan dan dibudayakan di lingkungan peserta didik agar yang bersangkutan selalu dalam kondisi kesehatan yang prima. Perkembangan ilmu pengetahuan dan teknologi menjadikan setiap negara termasuk Indonesia menghadapi tantangan untuk meningkatkan aktivitas olahraga warga negaranya, terlebih bagi negara maju, dimana manusianya dapat dikatakan sangat kurang dalam gerak jasmaninya, sehingga tidak jarangmenimbulkan gangguan-gangguan dalam metabolisme tubuh, sistem otot, tulang, jantung dengan pembuluh darah dan juga sistem syarafnya. Olahraga mempunyai benyak manfaat. Salah satunya memperbaiki dan menjaga kesegaran jasmani. Dengan mengikuti kegiatan olahraga, diharapkan seseorang dapat menikmati manfaat olahraga bagi kesehatannya. Selain itu, yang jauh lebih penting adalah melalui olahraga seseoarang diharapkan akan mampu bekerja dengan produktif dan efisien, tidak mudah terserang penyakit, belajar menjadi lebih semangat, serta dapat berprestasi secara optimal karena didukung oleh kebugaran atau kesegaran jasmani yang dimilkinya. Kesegaran jasmani adalah kemampuan seseorang untuk melakukan aktivitas sehari-hari dengan mudah tanpa merasa lelah berlebihan dan masih mempunyai cadangan tenaga untuk melakukan aktivitas yang lain. Melalui kegiatan olahraga yang teratur, terprogram dan terarah dengan baik maka akan 
tampak peningkatan derajat kesejahteraan atau kesegaran jasmaninya.Kesegaran jasmani merupakan suatu aspek penting dimiliki oleh setiap orang, hal ini disebabkan karena kesegaran jasmani menunjukkan kemampuan seseorang untuk dapat menyelesaikan pekerjaan yang dilakukan sehari-hari, baik sebagai siswa, mahasiswa, pegawai, petani ataupun lainnya. Oleh karena pentingnya memiliki kesegaran jasmani yang baik maka upaya untuk meningkatkan dan mempertahankan kesegaran jasmani ini sangat perlu dilakukan.Pengembangan kesegaran jasmani dalam pendidikan diberikan sejak usia dini di bangku sekolah dasar melalui pendidikan jasmani. Menurut standar kompetensi mata pelajaran pendidikan jasmani sekolah. Pendidikan Jasmani adalah proses pendidikan yang memanfaatkan aktivitas jasmani yangdirencanakan secara sistematik yang bertujuan untuk meningkatkan individu. Di dalam intensifikasi penyelenggaraan pendidikan sebagai suatu proses pembinaan manusia yang berlangsung seumur hidup, peranan Pendidikan Jasmani adalah sangat penting, yang memberikan kesempatan kepada siswa untuk terlibat langsung dalam aneka pengalaman belajar melalui aktivitas jasmani, bermain dan olahraga yang dilakukan secara sistematis. Pembekalan pengalaman belajar itu diarahkan untuk membina, sekaligus membentuk gaya hidup sehat dan aktif sepanjang hayat. Selain itu pendidikan jasmani juga bertujuan untuk mengembangkan aspek kesehatan, kebugaran jasmani, keterampilan berfikir kritis, stabilitas emosional, keterampilan sosial, penalaran dan tindakan moral melalui aktivitas jasmani dan olahraga.SMP Negeri 6 Tebing Tinggi selain merupakan sekolah favorit, juga merupakan sekolah yang peduli akan kegiatan olahraganya. Ini dibuktikan dengan adanya aktivitas gerak yang rutin dilaksanakan setiap hari jumat dengan bentuk senam dan jalan sehat bersama. Selain itu, SMP Negeri 6 Tebing Tinggi juga mewajibkan para siswanya untuk melakukan kegiatan ekstra kulikuler satu minggu satu kali guna dapat menciptakan siswa dengan kesegaran jasmani yang baik. Berdasar latar belakang masalah di atas, penulis tertarik untuk melakukan penelitian hubungan kesegaran jasmani terhadap hasil belajar siswa putra kelas VIII SMP Negeri 6 Tebing Tinggi.

Berdasarakan latar belakang diatas, maka identifikasi masalah dalam penelitian ini adalah :

a. Tes kesegaran jasmani siswa putra kelas VIII SMP Negeri 6 Tebing Tinggi belum pernah dilakukan.

b. Apakah dengan pendidikan jasmani yang sistematis dan dengan melakukan aktivitas olahraga rutin setiap hari jumat serta melakukan kegiatan ekstra kulikuler yang diadakan sekolah dapat meningkatkan kesegaran 
jasmani siswa putra kelas VIII SMP Negeri 6 Tebing Tinggi.

Setiap penelitian yang dikerjakan selalu mempunyai tujuan akhir untuk memperoleh gambaran yang jelas dan bermanfaat bagi yang menggunakannya. Adapun tujuan dari penelitian ini adalah Untuk mengetahui tingkat kesegaran jasmani siswa putra kelas VIII SMP Negeri 6 Tebing Tinggi? Untuk mengetahui hasil belajar siswa putra kelas VIII SMP Negeri 6 Tebing Tinggi? Untuk mengetahui hubungan antara tingkat kesegaran jasmani terhadap hasil belajar siswa?

\section{METODE PENELITIAN}

Metode yang digunakan dalam penelitian ini adalah survey test. Survei adalah merupakan bagian dari study deskriptif yang bertujuan untuk mencari kedudukan atau status,fenomena (gejala) dan menemukan kesamaan status dengan cara membandingkan standart yang sudah di tentukan Suharsimi Arikunto (2006:90). Secara umum metode penelitian diartikan sebagai cara ilmiah untuk mendapatkan data dengan tujuan dan kegunaan tertentu. Terdapat empat kata kunci yang perlu diperhatikan yaitu, cara ilmiah, data, tujuan, dan kegunaan tertentu. Cara ilmiah berarti penelitian itu didasarkan pada ciri-ciri keilmuan yaitu rasional, empiris, dan sistematis. Data berarti data yang diperoleh melalui penelitian itu adalah data empirisyang mempunyai kriteria tertentu yaitu valid (derajad ketepatan). Tujuan penelitian ada tiga macam yaitu yang bersifat penemuan, pembuktian, dan pengembangan. Kegunaannya untuk memahami, memecahkan dan mengantisipasi masalah.

Menurut Suharsimi Arikunto (2006:116), variabel adalah gejala yang bervariasi dan menjadi objek penelitian. Sedangkan menurut Sugiyono (2009:2), variabel adalah suatu atribut atau sifat atau nilai dari orang, obyek atau kegiatan yang mempunyai variasi tertentu yang ditetapkan oleh peneliti untuk dipelajari dan ditarik kesimpulannya. Dalam penelitian ini terdapat dua variabel yaitu variabel bebas dan variabel terikat. Variabel bebas merupakan variabel yang mempengaruhi atau menjadi sebab perubahannya atau timbulnya variabel terikat. Dalam penelitian ini yangmenjadi variabel bebas adalah kesegaran jasmani. Sedangkan variabel terikat merupakan variabel yang dipengaruhi karena adanya variabel bebas, jadi hasil belajar siswa merupakan variabel terikat dalam penelitian ini.

Populasi adalah keseluruhan subjek penelitian (Suharsimi Arikunto, 2006:130). Sedangkan menurut Sutrisno Hadi (2004:185) populasi adalah suatu penduduk yang masuk untuk diselidiki, populasi dibatasi sehingga penduduk atau individu yang paling sedikit mempunyai sifat yang sama. Dari pendapat di atas, penulis menyimpulkan bahwa populasi 
seluruh individu yang akan dijadikan subjek penelitian dan keseluruhan dari individu-individu yang harus memiliki sifat yang sama. Populasi dalam penelitian ini adalah siswa putra kelas VIII SMP Negeri 6 Tebing Tinggi yang berjumlah 92 siswa.Sampel adalah bagian dari jumlah dan karakteristik yang dimiliki oleh populasi. Bila populasi besar, dan peneliti tidak mungkin mempelajari semua yang ada pada populasi, maka peneliti dapat menggunakan sampel yang diambil dari populasi itu (Sugiyono, 2009:62).Sampel dari penelitian ini adalah 30 siswa kelas VIII. Sampel dipilih dengan teknik random sampling yang berarti setiap anggota populasi memiliki kesempatan yang sama untuk menjadi sampel.

Kesegaran jasmani erat kaitannya dengan kegiatan manusia dalam melakukan pekerjaan dan bergerak. Kesegaran jasmani yang dibutuhkan menusia untuk bergerak dan melakukan pekerjaan bagi setiap individu tidak sama. Untuk mengetahui dan menilai tingkat kesegaran jasmani seseorang dapat dilakukan dengan melaksanakan pengukuran. Pengukuran kesegaranjasmani dilakukan dengan tes kesegaran jasmani. Untuk melaksanakan tes diperlukan adanya instrumen atau alat tes. Tes kesegaran jasmani Indonesia (TKJI) merupakan salah satu instrumen untuk mengukur tingkat kesegaran jasmani.Lokakarya kesegaran jasmani tahun 1984 TKJI telah disepakati dan ditetapkan menjadi suatu instrumen yang berlaku di seluruh Indonesia. TKJI dibagi menjadi 4 kelompok umur, yaitu (1) umur 6-9 tahun, (2) 10-12 tahun, (3) 13-15 tahun, (4) 16-19 tahun. Dalam penelitian ini tes yang akan digunakan adalah tes kesegaran jasamani Indonesia (TKJI) kelompok umur 13-15 tahun. Rangkaian tes kesegaran jasmani Indonesia untuk remaja umur 13-15 tahun terdiri dari: (1) lari 50 meter, (2) gantung angkat tubuh 60 detik, (3) baring duduk 60 detik, (4) loncat tegak, (5) lari 1000 meter untuk putra dan 800 meter untuk putri.

Metode pengumpulan data adalah suatu cara untuk memperoleh keterangan yang benar sehingga dapat dipertanggungjawabkan. Dalam penelitian ini, metode yang digunakan dalam pengumpulan data adalah metode tes berupa tes kesegaran jasmani Indonesia (TKJI) yang mengukur tingkat kesegaran jasmani para siswa. Dalam tes ini meliputi lari 50 meter, gantung angkat tubuh 60 detik, baring duduk 60 detik, loncat tegak, dan lari 1000 meter dan metode dokumentasi untuk mengetahui hasil belajar yang dicapai siswa.

\section{HASIL PENELITIAN DAN PEMBAHASAN}

Penelitian ini dimaksudkan untuk mengetahui hubungan tingkat kesegaran jasmani dengan hasil belajar pada siswa putra kelas VIII SMP Negeri 6 Tebing Tinggi tahun 2017. Pengukuran tingkat kesegaran jasmani menggunakan tes 
pengukuran Tes Kesegaran Jasmani Indonesia (TKJI) untuk umur 13-15 tahun. Tes ini terdiri dari 5 item yaitu tes lari 50 meter, tes gantung angkat tubuh, baring duduk 60 detik, loncat tegak dan lari 1000 meter, sedangkan hasil belajar menggunkan nilai raport semester 2 .

Berdasarkan penelitian diatas dapat diketahui tingkat kesegaran jasmani siswa kelas VIII SMP Negeri 6 Tebing Tinggi adalah 0\% memiliki tingkat kesegaran jasmani yang kurang sekali, 3,33\% masuk dalam kategori kurang, 63,33\% masuk dalam kategori sedang, $33,33 \%$ masuk dalam kategori baik, 0\% masuk dalam kategori baik sekali. Secara umum tingkat kesegaran jamani siswa putra kelas VIII SMP Negeri 6 Tebing Tinggi tahun 2017 adalah sedang.

Berdasarkan penelitian Lari 50 Meter diatas dapat diketahui hasil tes 50 meter siswa kelas VIII SMP Negeri 6 Tebing Tinggi adalah 0\% memiliki tingkat kesegaran jasmani yang kurang sekali, $0 \%$ masuk dalam kategori kurang, 33,33\% masuk dalam kategori sedang, 56,7\% masuk dalam kategori baik, $10 \%$ masuk dalam kategori baik sekali. Secara umum hasil tes lari 50 meter siswa putra kelas VIII SMP Negeri 6 Tebing Tinggi tahun 2017 adalah baik.

Berdasarkan penelitian Gantung Angkat Tubuh diatas dapat diketahui hasil tes gantung angkat tubuh siswa kelas VIII SMP Negeri 6 Tebing Tinggi adalah 23,33\% memiliki tingkat kesegaran jasmani yang kurang sekali, 63,33\% masuk dalam kategori kurang, 13,33\% masuk dalam kategori sedang, 0\% masuk dalam kategori baik, 0\% masuk dalam kategori baik sekali. Secara umum hasil tes gantung angkat tubuh siswa putra kelas VIII SMP Negeri 6 Tebing Tinggi tahun 2017 adalah kurang.

\section{Pembahasan}

Pada hakikatnya, kesegaran jasmani adalah kemampuan fungsional dari alat-alat tubuh untuk melakukan aktifitas dengan penuh kewaspadaan dan dengan hasil yang memuaskan tanpa adanya kelelahan yang berarti serta masihmemiliki tenaga cadangan untuk aktivitasaktivitas yang akan datang yang mungkin menyita perhatiannya. Kesegaran jasmani adalah salah satu potensi fisik yang dimiliki setiap orang untuk meningkatkan produktivitas kerja. Bagi kalangan pelajar, kesegaran jasmani menjadi salah satu faktor yang mempengaruhi kesiapan fisik sebelum menerima pelajaran di sekolah sehingga nantinya dengan kesegaran fisik yang baik, siswa dapat menerima pengajaran yang diberikan oleh sekolah dengan optimal. Salah satu manfaat kesegaran jasmani bagi pelajar dan mahasiswa adalah mempertinggi kemauan dan kemampuan belajar. Dengan kesegaran jasmani yang baik, diharapkan siswa mempunyai tingkat konsentrasi yang tinggi untuk mendapatkan pelajaran yang disampaikan oleh bapak ibu gurunya. Kualitas kecerdasan intelektual 
individu dipandang sebagai faktor utama yang mempengaruhi keberhasilan individu dalam meraih kesuksesan belajar. Namun keberhasilan belajar individu bukan hanya ditentukan oleh tingginya kecerdasan intelektual tetapi juga ditentukan oleh berbagai faktor. Faktor yang mempengaruhi belajar tersebut dibagi menjadi dua golongan, yaitu faktor internal dan eksternal.Faktor internal atau kondisi internal ini mencakup kondisi fisik, seperti kesehatan organ tubuh, kondisi psikis, seperti kemampuan intelektual, emosional; dan kondisi sosial, seperti kemampuan bersosialisasi dengan lingkungan. Sedangkan faktor eksternalnya antara lain seperti variasi dan tingkat kesulitan materi belajar (stimulus) yang dipelajari (direspon), tempat belajar, iklim, suasana lingkungan, dan budaya belajar masyarakat akan mempengaruhi kesiapan, proses, dan hasil belajar.Faktor internal yang mencakup kondisi fisik seseorang memiliki peran penting dalam menentukan keberhasilan belajar. Proses belajar seseorang akan terganggu jika berada dalam kondisi yang kurang sehat, cepat lelah, kurang bersemangat, mudah pusing, mengantuk, ataupun gangguan fungsi alat penginderaan dan organ - organ lainnya. Dari penjelasan diatas dapat ditarik kesimpulan bahwa, kesegaran jasmani merupakan salah satu faktor yang mempengaruhi hasil belajar siswa. Tingkat kesegaran jasmani siswa mempunyai peran penting terutama dalam mengikuti proses kegiatan belajar. Kesegaran jasmani berperan penting dalam mempertinggi kemauan dan kemampuan belajar, sehingga dengan kesegaran jasmani yang baik maka dapat mendukung terciptanya hasil belajar yang baik pula. Berdasarkan kesimpulan ini maka penting bagi siswa untuk senantiasa memperhatikan serta meningkatkan kesegaran jasmaninya. Hal ini bertujuan agar siswa mempunyai modal utama untuk melakukan kegiatan sehari-hari tanpa mengalami kelelahan yang berarti, sehingga lebih bersemangat untuk meningkatkan prestasi belajarnya.

\section{SIMPULAN}

Berdasarkan uraian dan data hasil penelitian dan pembahasan maka peneliti dapat menarik kesimpulan yaitu:

a. Tingkat kesegaran jasmani siswa putra kelas VIII SMP Negeri 6 Tebing Tinggi tahun 2017 berkategori kurang sebanyak 1 responden atau 3,33\%, berkategori sedang sebanyak 19 responden atau $63,33 \%$ dan berkategori baik sebanyak 10 responden atau 33,33\% dari 30 siswa yang diteliti. Sebagian besar tingkat kesegaran jasmani siswa putra kelas VIII SMP Negeri 6 Tebing Tinggi tahun 2017 berkategori sedang sebanyak 19 responden atau $63,33 \%$. Dengan hasil tersebut menunjukkan bahwa tingkat kesegaran jasmani siswa putra kelas VIII SMP Negeri 6 Tebing 
Tinggi tahun 2017 berada dalam kategori sedang.

b. Hasil belajar siswa kelas VIII SMP Negeri 6 Tebing Tinggi tahun 2017berkategori baik sebanyak 30 responden atau 100\% dari 30 siswa yang diteliti. Dengan hasil tersebut menunjukkan bahwa tingkat hasil belajar siswa putra kelas VIII SMP Negeri 6 Tebing Tinggi tahun 2017 berada dalam kategori baik.

c. Hasil penelitian menunjukan adanya hubungan antara tingkat kesegaran jasmani dengan hasil belajar siswa kelas VIII SMP Negeri 6 Tebing Tinggi tahun 2017, hal ini ditunjukan dari besarnya nilai $r$ yaitu 0,620 .

\section{DAFTAR RUJUKAN}

Achmad Rifa'i R. C dan Catharina Tri Anni. 2010. Psikologi Pendidikan. Semarang: UNNES Press.

Djoko, Pekik. 2004. Pedoman Praktis Berolahraga untuk Kebugaran dan Kesehatan.Yogyakarta: Andi Offset.

Dangsina Moeloek. 1984. Dasar Fisiologi Kesegaran Jasmani dan Latihan Fisik. Jakarta: Bagian Ilmu Faal Fakultas Kedokteran Universitas Indonesia.

H. Y. S. Santoso G. Dan Dikdik Zafar S. 2012. Ilmu Faal Olahraga. (Fisiologi Olahraga). Bandung: PT Remaja Rosda Karya.
Khomsin (edt). 2010. Buku Panduan Tes Kesegaran Jasmani Indonesia (TKJI). Jakarta: Pusat Pengembangan Kualitas Jasmani

M. Sajoto. 1988. Pembinaan Kondisi Fisik dalam Olahraga. Jakarta: Deparrteman Pendidikan dan Kebudayaan Direktorat Jendral Pendidikan Tinggi.

Mailani, E. 2016. Upaya Meningkatkan Hasil Belajar Matematika Pada Materi Pecahan Melalui Permainan Monopoli Pecahan. JURNAL HANDAYANI PGSD FIP UNIMED, 4(1).

Muhibbin, Syah. 2000. Psikologi Pendidikan dengan Suatu Pendekatan baru. Bandung: PT. Remaja Rosdakarya.

Rubianto Hadi. 2010. Ilmu Kepelatihan Dasar.

Sadoso Sumosardjono. 1986. Pengetahuan Praktis Kesehatan Dalam Olahraga. Jakarta : P.T. Gramedia.

Sharkey, B.J. 2003. Fitness And Health. Alih bahasa Kebugaran dan Kesehatan oleh: Eri Desmarini Nasution. Jakarta: PT. Raja

Sugiyono. 2009. Statistika untuk Penelitian. Bandung: Alfabeta. 